\title{
Pelagic phytoplankton community change-points across nutrient gradients and in response to invasive mussels
}

\author{
KATYA E. KOVALENKO*, EUAN D. REAVIE*, J. DAVID ALLAN ${ }^{\dagger}$, MEIJUN CAI*, SIGRID D. P. SMITH $^{\dagger}$ ** \\ AND LUCINDA B. JOHNSON* \\ *Natural Resources Research Institute, University of Minnesota Duluth, Duluth, MN, U.S.A. \\ †School of Natural Resources and Environment, University of Michigan, Ann Arbor, MI, U.S.A.
}

\section{SUMMARY}

1. Phytoplankton communities can experience nonlinear responses to changing nutrient concentrations, but the nature of species shifts within phytoplankton is not well understood and few studies have explored responses of pelagic assemblages in large lakes.

2. Using pelagic phytoplankton data from the Great Lakes, we assessed phytoplankton assemblage change-point responses to nutrients and invasive Dreissena, characterising community responses in a multi-stressor environment and determine whether species responses to in situ nutrients can be approximated from nutrient loading.

3. We demonstrate assemblage shifts in phytoplankton communities along major stressor gradients, particularly prominent in spring assemblages, providing insight into community thresholds at the lower end of the phosphorus gradient and species-stressor responses in a multi-stressor environment. We show that responses to water nutrient concentrations could not be estimated from large-scale nutrient loading data likely due to lake-specific retention time and long-term accumulation of nutrients.

4. These findings highlight the potential for significant accumulation of nitrates in ultra-oligotrophic systems, nonlinear responses of phytoplankton at nutrient concentrations relevant to current water quality standards and system-specific (e.g. lake or ecozone) differences in phytoplankton responses likely due to differences in nutrient co-limitation and effects of dreissenids.

Keywords: algae, community thresholds, Dreissena, eutrophication, water quality

\section{Introduction}

Cycling of nitrogen and phosphorus, the two most limiting nutrients for primary production, has been greatly altered by human activities (Falkowski, Fenchel \& Delong, 2008; Galloway et al., 2008; Canfield, Glazer \& Falkowski, 2010; Bouwman et al., 2013). Primary producers are strongly affected by nutrient limitation (e.g. Tilman, 1982; Wetzel, 2001), and changes in their assemblages in response to nutrients propagate up the food web through a multitude of pathways including decreased diversity, increased biomass turn-over and overwhelming contribution of bloom taxa to the overall energy flow (McCann \& Rooney, 2009). In the pelagic zones of lakes, phytoplankton directly respond to many stressors associated with human development such as excess nutrients, and can therefore be one of the early-warning signals for ecosystem change in response to stress (McCormick \& Cairns, 1994).

There is evidence that algal communities can experience nonlinear changes in response to increasing nutrient concentrations (Smucker et al., 2013a). The abrupt transition from macrophyte-dominated to an algal-dominated state is one of the classic examples of alternative stable states (Scheffer \& Jeppesen, 1998); however, the nature of species shifts within the phytoplankton assemblage is not as well documented. In addition to nutrient loading, proliferation of invasive filter feeders has been

Correspondence: Katya E. Kovalenko, Natural Resources Research Institute, University of Minnesota Duluth, 5013 Miller Trunk Highway, Duluth, MN 55811-1442, U.S.A. E-mail: philarctus@gmail.com

*Present address: College of Agriculture and Related Sciences, Delaware State University, Dover, DE, U.S.A. 
linked to major shifts in primary producer community composition due to grazing and the resulting broader changes in food-web structure and nutrient cycling across aquatic ecosystems such as the shift from mostly pelagic to benthic-littoral energy pathways (Higgins \& Vander Zanden, 2010; Karatayev, Burlakova \& Padilla, 2015a; Gallardo et al., 2016). Understanding the degree of nonlinearity in phytoplankton assemblage shifts and identifying key species responding to these anthropogenic stressors is necessary to relate changes in water quality, nutrient cycling and precipitation patterns to the rest of the food web. This approach can contribute strong ecology-based evidence for developing nutrient criteria (Smucker et al., 2013a) and is particularly important since there are few biotic indicators available for the pelagic zones of large lakes, making it difficult to monitor assemblage responses to such large-scale stressors as invasive species and nutrient loading.

The Laurentian Great Lakes have a long history of anthropogenic stress affecting phytoplankton, often resulting in undesirable effects such as cultural eutrophication (Stoermer, 1978). Excess phosphorus loading has most commonly been cited as the major causal agent in water quality and algal problems (Conley et al., 2009). Nitrogen concentrations in the Great Lakes region have also increased greatly over the past century (Han \& Allan, 2012) and are likely implicated in changes throughout the ecosystem (e.g. Elser et al., 2010). Effects of nitrogen loading on pelagic phytoplankton dynamics received less attention than effects of phosphorus (but see Reavie, Heathcote \& Shaw Chraibi, 2014a); but, there is evidence of nitrogen limitation and co-limitation of coastal algal biofilms (Cooper et al., 2016). More recently, the extensive invasion of zebra and quagga mussels (Dreissena polymorpha and D. bugensis: Dreissenidae) throughout most of the basin has greatly impacted primary production in the lakes by shunting energy flow from the pelagic to the benthic food web (Hecky et al., 2004; Bunnell et al., 2014). This has further altered phytoplankton communities, particularly in Lake Michigan and Lake Huron (Reavie et al., 2014b), but the mechanistic processes that drive these phytoplankton changes are still under discussion (e.g. Kerfoot et al., 2010). This dreissenid invasion was ranked as the top environmental threat out of the comprehensive list of 50 stressor variables in the Great Lakes, according to a recent expert survey (Smith et al., 2015), and is probably the most important stressor relevant to pelagic autotrophs along with atmospheric nutrient deposition.

We examined responses of phytoplankton communities to Dreissena abundance and nitrogen $(\mathrm{N})$ loading as well as in situ water nitrate and total phosphorus concentrations, known to be relevant in water predictors for phytoplankton assemblages based on previous studies (Reavie et al., 2014a). Some of the predictors examined in our study are not necessarily stressors from the perspective of phytoplankton; however, these predictors are often referred to as stressors for consistency with other studies and to reflect the general perception of nutrient loading. Our major goals were to (i) test whether there is a relationship between nitrogen loading and water nitrate concentrations, (ii) determine whether there is evidence of nonlinear changes in phytoplankton assemblage composition in response to in situ nutrient concentrations and estimates of offshore environmental stress (nitrogen loading and Dreissena abundance) and (iii) examine key species responses along the stressor gradients, characterise assemblage responses in a multi-stressor environment and test whether large-scale estimates of nutrient loading can be related to similar assemblage responses as in situ water nutrient concentrations.

\section{Methods}

\section{Data collection and processing}

The pelagic zones of the Laurentian Great Lakes, which encompass lakes Erie, Ontario, Huron, Michigan and Superior, range from ultra-oligotrophic in the northern GL to eutrophic-mesotrophic in the south. The standard operating procedure for phytoplankton collection and analysis is described in detail in the published procedures (USEPA, 2010) and a comprehensive summary is provided by Reavie et al. (2014a). Briefly, water samples were collected during biannual synoptic sampling ('spring' - April, 'summer' - August) from 72 standard pelagic stations throughout the Great Lakes (Fig. 1), with each station sampled each year in April and August for a total of eight samples per station (2007-10). Integrated water samples were collected from the rosette sampler onboard the $R / V$ Lake Guardian. In the laboratory, water samples were digested by acid persulfate and measured by a Lachat QuikChem AE autoanalyzer (Hach Company, Loveland) for total phosphorus (Barbiero et al., 2006). Nitrate + nitrite $\left(\mathrm{NO}_{\mathrm{x}}\right)$ concentrations, hereafter referred to as nitrate due to much lower nitrite concentrations in open water, were determined by diazotising with sulfanilamide dihydrochloride after nitrate was reduced by copper-coated cadmium (GLNPO, 2010). We used $\mathrm{NO}_{x}$ because organic $\mathrm{N}$ and ammonia were a very minor component of the $\mathrm{TN}$ budget $(<0.2 \%)$ and were no longer being measured at the pelagic 


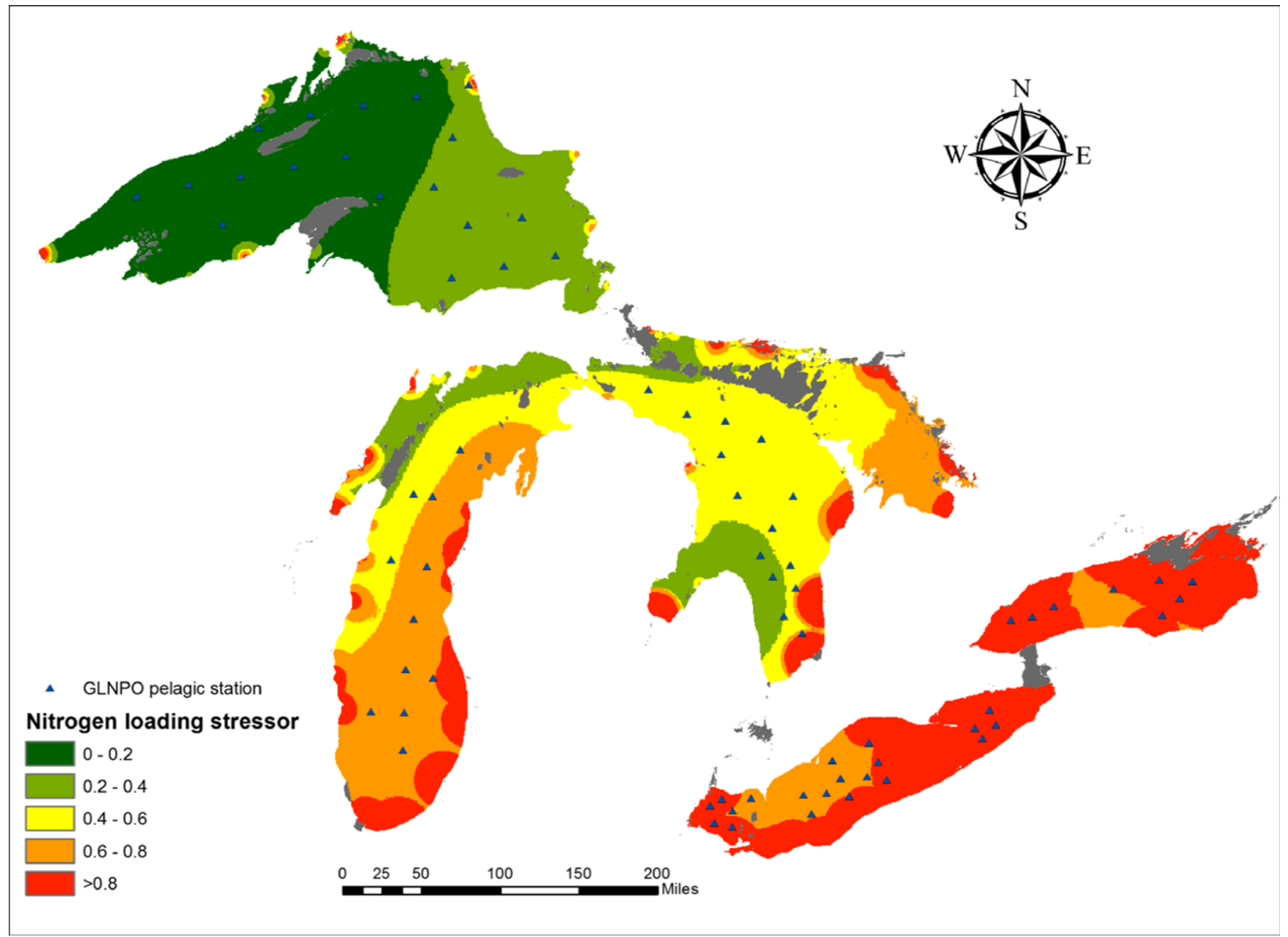

Fig. 1 Map of pelagic sampling stations in the Great Lakes superimposed on estimates of nitrate loading (percentile/quintiles) across the basin. See main text and Allan et al. (2013) for more details on nitrogen deposition and USEPA (2010) and Reavie et al. (2014a) for more details on the sampling stations.

stations during the years of this study. We used total phosphorus (TP), because most of phosphorus is bound in seston, the inorganic compartment is generally very small $(<1 \%$, Wetzel, 2001) and the overall productivity is determined by TP and the rate of cycling between the inorganic and particulate $\mathrm{P}$ compartments. Because mean values of water quality parameters can be skewed by extreme values (Helsel \& Hirsch, 2002), we used median water quality from 2007 to 2010 in all analyses.

Phytoplankton samples were composites of water sampled at discrete depths from the euphotic zone of the water column (the entire water column during isothermal spring conditions and the epilimnion during summer). Samples were analysed for the whole phytoplankton assemblage. Analysis of soft algae used the quantitative Utermöhl method (Utermöhl, 1958), while acid digestions were used to isolate diatom valves which were then plated on slides and counted using oil immersion [1000 $\times$ or higher; valve counts: at least 500 per sample, soft algae: at least 250 'entities' (colonies, filaments, cells) per sample]. Dead diatoms (empty frustules) were not included in final counts. As with water quality, each station was sampled twice each year in April and August. Only 2008-10 data were used because previous studies demonstrated strong changes in assemblage composition prior to this period (Reavie \& Barbiero, 2013).

We used environmental stressor data from the Great Lakes Environmental Assessment and Mapping project (GLEAM), which overall aimed to synthesise the cumulative impact of 34 stressors across the Great Lakes (Allan et al., 2013). For nitrogen loading, 2003-07 atmospheric deposition of nitrate was compiled from the National Atmospheric Deposition Program (NADP) for wet nitrate deposition (via rain, fog and snow) and Clean Air Status and Trends Network (CASTNET) for 
dry deposition; dry:wet deposition ratios were used to estimate 5-year averages of total deposition of nitrate (dry + wet) across the surfaces of the lakes (Han \& Allan, 2012; Allan et al., 2013). Nitrogen loading also included estimates of tributary loadings in addition to $\mathrm{N}$ atmospheric deposition; however, for most offshore pelagic stations, total inputs were dominated by deposition because tributary loading rapidly declined away from the coastline, to $10 \%$ of initial levels at $15 \mathrm{~km}$. Although water nitrate concentrations were determined contemporaneously with phytoplankton assessment (2007-10), whereas $\mathrm{N}$ loading was estimated from earlier data (2003-07), large-scale N loading is unlikely to have changed greatly during this time period. Unlike $\mathrm{N}$ loading, it was not possible to compare assemblage responses to water TP versus $\mathrm{P}$ loading, because tributary loading data were highly skewed (little tributary $\mathrm{P}$ was detectable offshore) and atmospheric deposition was minor and not well-quantified (Allan et al., 2013). For invasive mussels, point observations (2000-06 time range) in numbers per $\mathrm{m}^{2}$ (e.g. Lozano, Scharold \& Nalepa, 2001; Dermott \& Geminiuc, 2003; Nalepa et al., 2007; Watkins et al., 2007; Nalepa et al., 2014; T. Nalepa, unpubl. data) were kriged to produce continuous maps of zebra and quagga mussel densities across the surfaces of the lakes (Allan et al., 2013). Both raster layers were transformed with a cumulative distribution function to express the data as percentiles relative to all other pixels in the five Great Lakes.

Multi-year data on environmental variables and phytoplankton assemblage composition were averaged by station to avoid pseudoreplication of the nutrient loading data; averaging was done separately for each season to reflect distinct seasonal dynamics of these assemblages (e.g. Reavie et al., 2014a). To link GLEAM stress variables with phytoplankton data, we created a $5-\mathrm{km}$ buffer (diameter $=10 \mathrm{~km}$ ) around each phytoplankton sampling station, and averaged the $\mathrm{N}$ loading and Dreissena abundance values within the buffer. This buffer distance was chosen for its water quality/biological relevance (P. Yurista, pers. comm.) and to account for the fact that the actual pixel/cell that a sampling site falls on can be slightly misaligned from projection conversions. The stressor layers are estimated via propagation from point data, so averaging over a larger area reduces the risk that an individual pixel might be an outlier.

\section{Analytical approaches}

Community responses were analysed using Thresholds Indicator Taxa Analysis (TITAN; King \& Baker, 2010).
This approach combines Indicator Species Analysis (Dufrêne \& Legendre, 1997) and change-point analysis to determine indicator values for each candidate changepoint along the stressor gradient, and then uses bootstrapping to identify reliable indicator taxa. Community threshold is identified by the synchronous change in abundance of many taxa, an approach that is more sensitive than methods considering composite metrics (richness, diversity) or combining sensitive and tolerant taxa, because it does not aggregate taxa responses prior to analysis (Baker \& King, 2010; King \& Baker, 2010). Species present in fewer than four stations (c. 10\% of observed species) were removed from the analysis. Species data were $\log (x+1)$-transformed prior to analysis. The following criteria were used to judge evidence for community thresholds: synchronous shifts in many species and strong responses of individual species (large standardised change in abundance, narrow bootstrapped quantile intervals). It is acknowledged that change-point identification is inherently subjective and may depend on frequency of observations across the stressor gradient, sample size and total number of taxa (Daily et al., 2012; Kovalenko et al., 2014). The degree of change ( $z$-score) values of significant and reliable indicators in response to each stressor were combined in a heatmap visualisation (NMF package in R, Gaujoux \& Seoighe, 2010), and cluster analysis was used to highlight taxa with similar responses and identify overlaps among assemblages responding to different stressors. For instance, if spring and summer assemblage responses to dreissenids were similar, we would expect these two seasonal assemblage responses to cluster close together. Analyses were based on density data (cells $\mathrm{mL}^{-1}$ ), which is appropriate for analyses of community composition using these approaches. All analyses were done in R (version 3.0.2; R Development Core Team, Vienna).

Human activity across large scales is unavoidably confounded with geography, and in the Great Lakes, most of the agricultural activity and settlement have occurred in the southern part of the basin (Danz et al., 2007). Due to the resulting differences in stressor distribution as well as differences in phytoplankton assemblage composition, we conducted separate analyses for the northern Great Lakes (NGL: Superior, Huron, Michigan) and southern Great Lakes (SGL: Erie, Ontario). Linear regressions were used to check the relationships among stressors within each ecoregion. Because overall nutrient budgets reflect nutrient loading and water retention time, we used ANCOVA to relate nitrate dynamics to lake retention time. In addition, we tested lake-specificity of the key species responding to stressor gradients 
to ensure that community changes were not driven by biogeographic limitations in species distributions by determining the proportion of species within each ecoregion which were confined to a single lake.

\section{Results}

Relationships between the stressors, particularly $\mathrm{N}$ loading, water nitrate concentrations and Dreissena abundance, were dependent on ecoregion, season and lake water retention time (Table S1). In NGL (Superior, Huron, Michigan), there was a significant negative relationship between water nitrate and large-scale estimates of $\mathrm{N}$ loading (Fig. 2, $r=-0.83$ and -0.78 in spring and summer, respectively, $P<0.001$ ). This relationship was mostly due to high water nitrate concentrations but low $\mathrm{N}$ loading rates in Lake Superior, although without this lake it was still marginally significant and negative $(r=-0.38, P=0.060$ in spring and $r=-0.41, P=0.040$ in summer). ANCOVA demonstrated that this relationship between water and atmospheric-deposited nitrate was highly correlated with lake retention time in spring $(P<0.001)$, but only marginally so in the summer (retention time effect $P=0.11$, see Table S1 for model details). Dreissena were absent in pelagic Lake Superior, but even without this lake, there was still a significant relationship between large-scale estimates of Dreissena abundance and water nitrate concentrations, particularly in the summer $(r=-0.41, P=0.044$ in spring, $r=-0.94$, $P<0.001$ in summer), as well as spring TP (Fig. 3, $r=0.76, P<0.001$ spring, $P=0.48$ summer). In SGL (Erie, Ontario), patterns were quite different: there was a positive relationship between $\mathrm{N}$ loading and spring but not summer water nitrate concentrations $(r=0.63$, $P<0.001$ spring, $P=0.19$ summer), and a positive relationship between Dreissena and water nitrate (Spearman's $D=1436 P=0.002$ in spring, and $D=1778$, $P=0.007$ in summer). The effect of water residence time was not tested due to relatively negligible differences in residence time between Erie and Ontario (2.7 and 6 years, compared with 173, 62 and 21 years for Superior, Michigan and Huron respectively). Stations with the highest nitrate and Dreissena densities were primarily in the western basin of Lake Erie. Water TP was not related to any other stressors in the SGL (Fig. 3, Table S2a).

Despite these distinct stressor profiles even within ecoregions, indicator lake-specificity analyses demonstrated that only eight of $88(9 \%)$ indicator species responsible for changes in assemblages were confined to a single lake in the NGL (Table S3). Nearly half of the species were present at $60 \%$ of the sampling stations. In the SGL, 30\% of 115 indicator species were lake-specific. It is therefore likely that observed species responses were in fact driven by stressors and not biogeographic limitations as many of the sensitive and tolerant species had broad geographic distributions. Overall, phytoplankton species richness had variable relationships with the stressors depending on region and season. The strongest trends were the decline in richness with
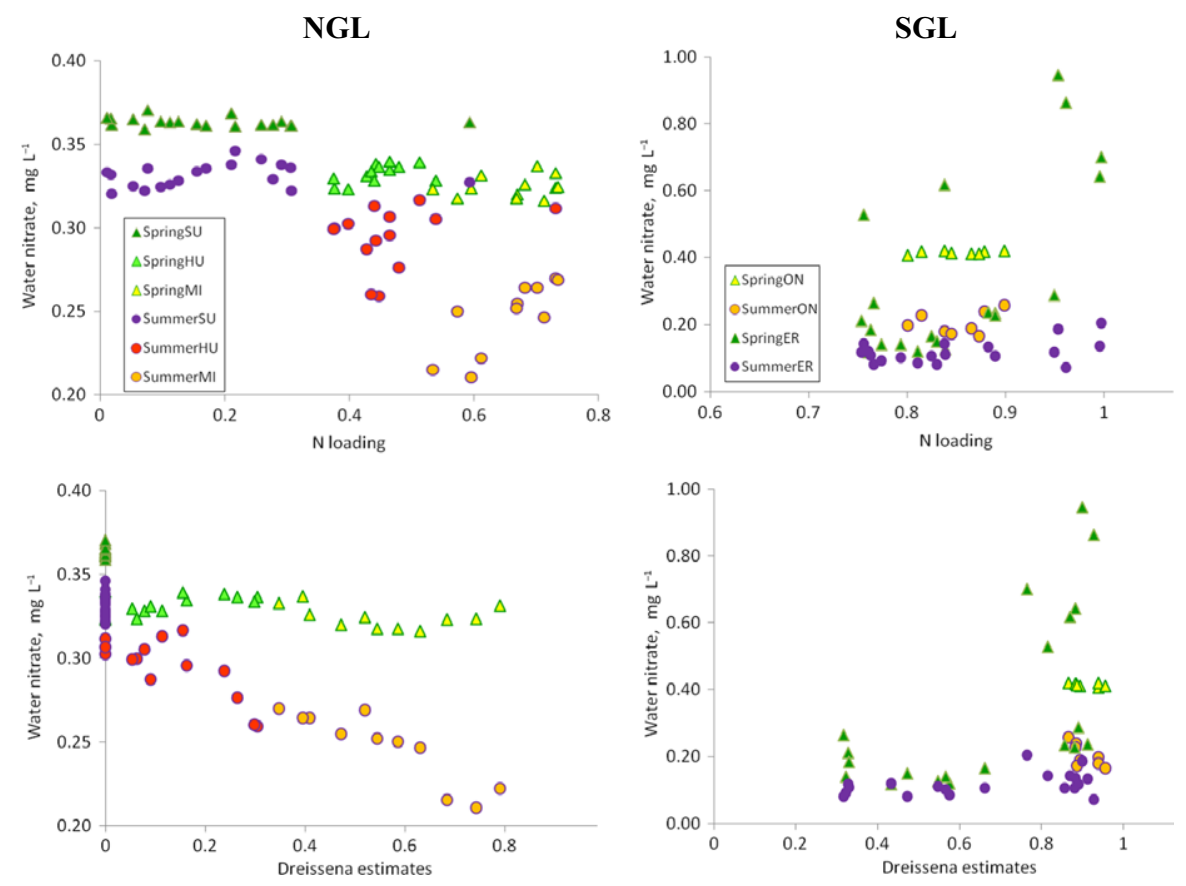

Fig. 2 Relationship between water nitrate and nitrogen $(\mathrm{N})$ loading and Dreissena densities in northern (SU Superior; HU - Huron, MI - Michigan) and southern Great Lakes (ER - Erie, ON - Ontario). Transformed Dreissena and $\mathrm{N}$ loading estimates are presented as unitless measures. Colour figure can be viewed at wileyonlinelibrary.com. 
Fig. 3 Relationship between total phosphorus and Dreissena and nitrogen (N) loading in NGL (SU - Superior; HU Huron, MI - Michigan) and SGL (ER Erie, ON - Ontario). Note the large differences in scale in the two regions. Lake Superior was excluded from statistical testing of TP versus Dreissena relationship. Transformed Dreissena and N loading estimates are presented as unitless measures. Colour figure can be viewed at wileyonlinelibrary.com.
NGL
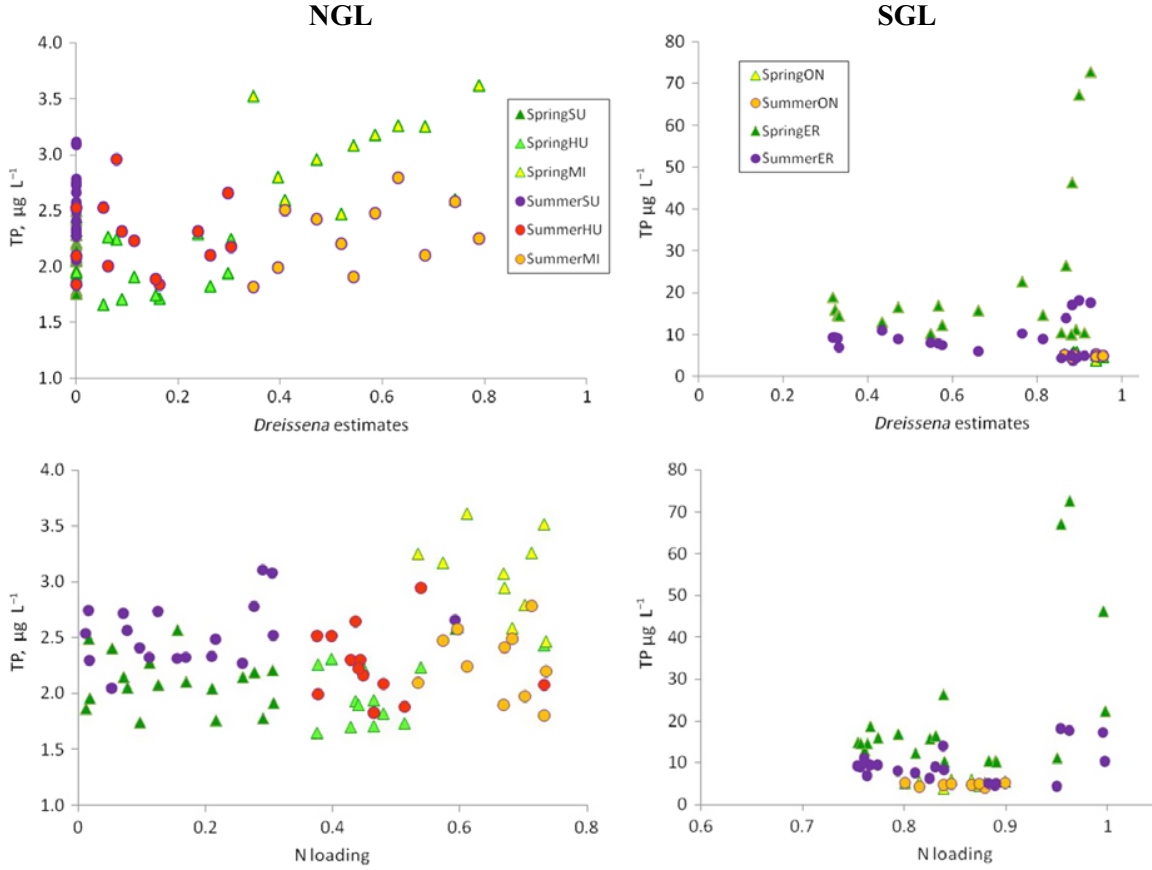

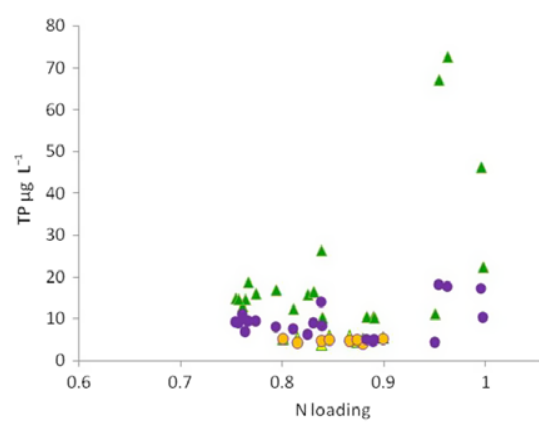

increasing Dreissena and TP in spring NGL assemblages, and increase with increasing $\mathrm{TP}$ and nitrate concentrations in spring SGL assemblages (Fig. 4, Table S2b).

There were change-point shifts in phytoplankton assemblages in response to major nutrients (water TP and water nitrate) and Dreissena abundance (Figs 5-7). In general, responses consistent with the threshold model can be characterised by a large number of individual indicator species and narrow quantile intervals around their change-points. In many cases, evidence for assemblage threshold response was not very strong, particularly for sensitive taxa. Stronger evidence of thresholds was observed for nitrate-spring-NGL-sensitive and tolerant, Dreissena-spring-NGL-sensitive and tolerant and Dreissena-summer-NGL-sensitive (Fig. 5, Figure S1a; Table S4 for change-point locations). Stronger assemblage responses to the above-mentioned stressors were observed in spring rather than summer, as indicated by the more pronounced assemblage thresholds (more synchronous responses of a greater number of species, Figs 5 \& 6) in the NGL, whereas in the SGL, this trend was not obvious. Many taxa with preferences for higher nutrient concentrations increased in response to TP and nitrate, but particularly with TP, this change was more gradual.

Assemblages in the NGL responded more strongly to water nitrate and Dreissena in terms of the number of sensitive and tolerant species changing in abundance with increasing levels of stress. Highest levels of these stressors were associated with distinct assemblages (see below). Many more tolerant taxa increased at higher nutrient concentrations, particularly $\mathrm{TP}$, than declined at the sensitive species threshold; this was most clearly visible with the greater number of tolerant (red) than sensitive (green) blocks within each TP column (Fig. 7).

Based on cluster analysis of species-stressor responses (Fig. 7, top), responses to nutrients in the southern basin are a distinct property of the Great Lakes phytoplankton assemblages (leftmost four variables in cluster analysis). Nitrate responses in the northern basin (right-most two variables) also stand out. Based on cluster analysis of the species-specific responses to multiple variables (Fig. 7, clustering on the left), we characterised 10 distinct groups of taxa with unique combinations of responses along the various gradients of pelagic stressors and water quality data. We briefly present and discuss these groups below, acknowledging that smaller taxonomic groups within these groups are possible. We provide the details of the clustering results (Fig. 7) so that readers may further characterise autecological data for taxa, if desired.

1. $N$ tolerant (NGL, spring and summer), dreissenid sensitive (NGL, summer). This group of taxa is tolerant of higher $\mathrm{N}$ concentrations in the water. These taxa also tend to occur in areas that have been less influenced by the dreissenid invasion. Cosmarium phaseolus, Monoraphidium irregulare, Crucigenia quadrata and Synedra filiformis var. exilis were among the species with the strongest stressor responses in this group.

2. Dreissenid sensitive (NGL, spring). Unlike the group above, these taxa are more specifically sensitive to 
NGL
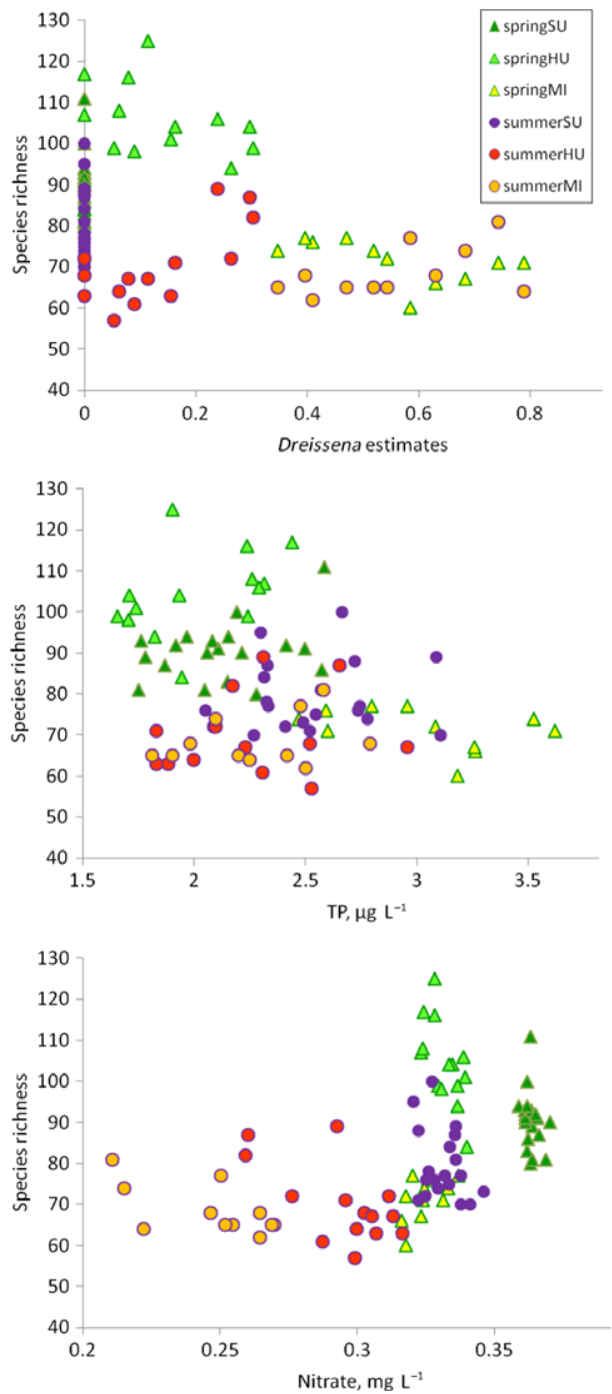

SGL
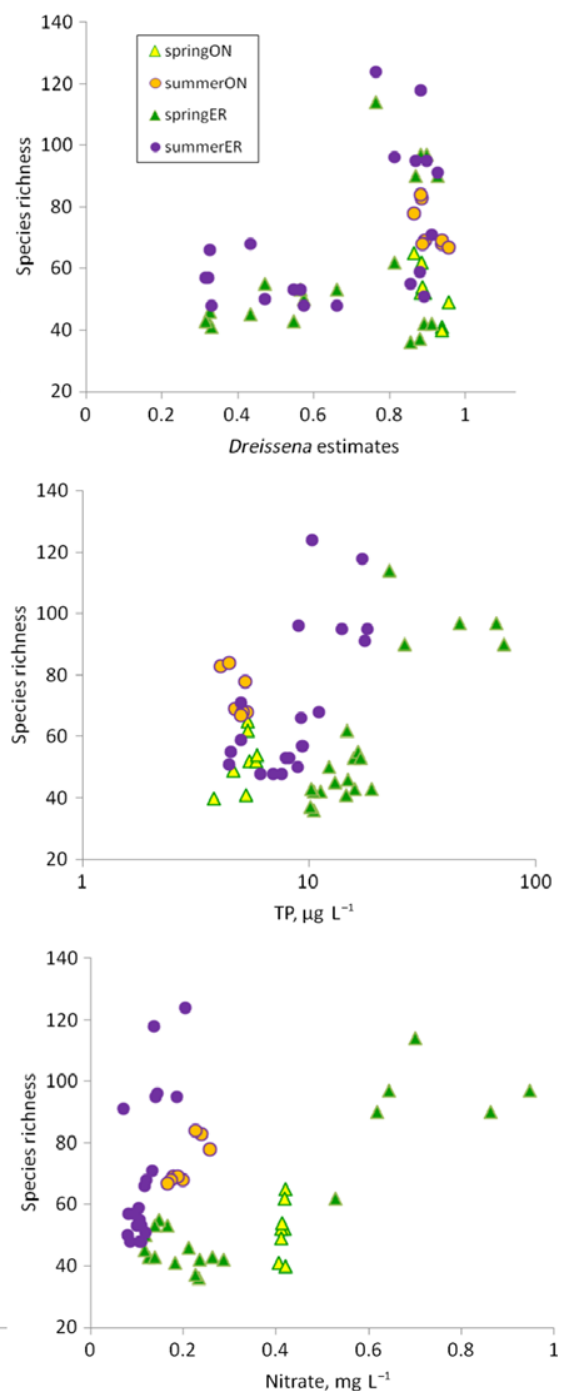

Fig. 4 Relationships between phytoplankton species richness and Dreissena, TP and nitrate in NGL (SU - Superior; HU - Huron, MI - Michigan) and SGL (ER - Erie, ON - Ontario). Colour figure can be viewed at wileyonlinelibrary.com. dreissenids in the spring, including Kephyrion cupuliformae and Stephanodiscus conspicueporus.

3. $N$ and $P$ tolerant (SGL, spring). This group of nutrient-tolerant taxa includes species that are well-known indicators of nutrient pollution, such as Cyclotella meneghiniana (e.g. Kwandrans et al., 1998) and Gomphonema olivaceum (Kelly \& Whitton, 1995). Cyclotella operculata and Cymbella minuta var. silesiaca responded the strongest along the nutrient gradient.

4. Dreissenid tolerant (NGL), $P$ tolerant (NGL, spring), $N$ sensitive (NGL). This small group of taxa includes
Cyclotella michiganiana, Fragilaria crotonensis, Rhodomonas lens and Diatoma tenue var. elongatum. Based on recent phytoplankton data from Lake Michigan (the lake with the greatest dreissenid abundance), Rhodomonas lens (a cryptophyte) and Fragilaria crotonensis (a pennate diatom), for instance, comprise a relatively large proportion of the summer assemblage, despite losses due to the dreissenid advance the decade prior (Reavie et al., 2014b).

5. Diverse responses but generally $P$ and dreissenid tolerant (spring) and $N$ sensitive (NGL, spring). These taxa apparently have multiple, simultaneous responses along

Fig. 5 Phytoplankton community thresholds in NGL (Superior, Huron, Michigan) in response to Dreissena densities, water nitrate and TP in (a) spring and (b) summer. Change-points (0.05-0.95 bootstrap quantile intervals) are shown for significant sensitive (filled, left side) and tolerant (open) taxa. Indicator value $P$-value cutoff $=0.05$; purity and reliability cutoffs $=0.8$ (consistency with which indicator taxa are assigned to each indicator group and consistency of significant IndVal scores across bootstrap replicates). See Table S5 for species codes and authorities. Note that $x$-axis is adjusted to display the entire range of observed stressor values for each scenario. 

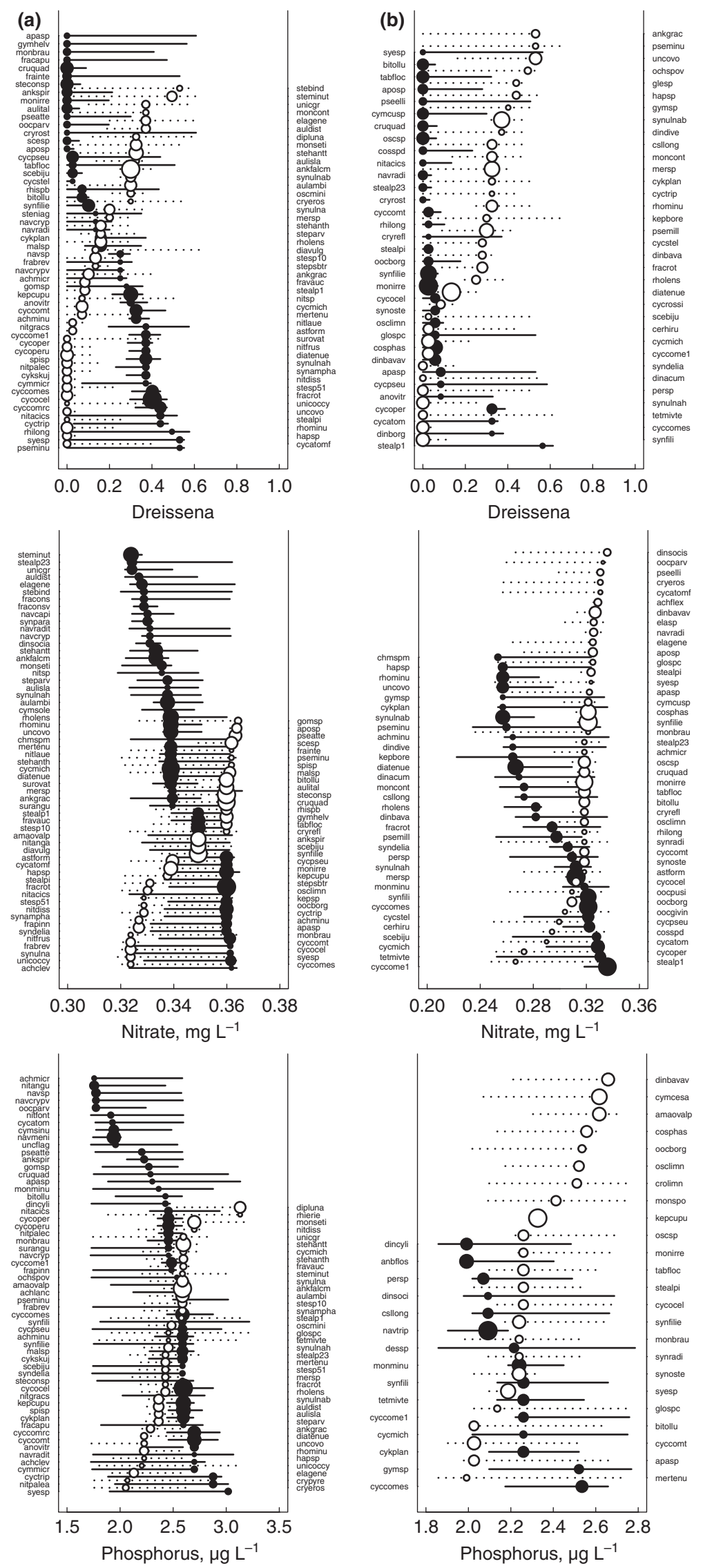
the environmental gradients tested, but a number of known nutrient-tolerant taxa are included, such as Stephanodiscus alpinus and S. binderanus (Reavie et al., 2014a).

6. Dreissenid tolerant and $N$ sensitive (NGL, summer). This is another group that seems limited by water nitrate concentrations, which includes taxa that are known to occur in the dreissenid-heavy Lake Michigan in the summer (e.g. Pseudokephyrion millerense; Reavie et al., 2014a).

7. Stressor-specific. While individual taxa have stressor-specific responses, for the most part, these taxa had few responses or did not adequately fit within other groups. These taxa may hold promise for stressor-specific monitoring.

8. $P$ tolerant (SGL, summer). This group was largely defined by a unique tolerance to higher summer phosphorus in the southern GL. Several taxa in this list (e.g. Aulacoseira granulata, Cyclostephanos dubius, Microcystis aeruginosa and Aphanizomenon flos-aquae) are well-known indicators of phosphorus-enriched summer conditions in Lake Erie (Reavie et al., 2014b). Nitzschia subacicularis, $N$. inconspicua and Scenedesmus opoliensis were among the most strongly responding species.

9. Dreissenid tolerant and $N$ sensitive (NGL, spring). These taxa, including Stephanodiscus hantzschii f. hantzschii and Rhodomonas minuta, were intolerant of higher $\mathrm{N}$ concentrations. However, these tend to be spring taxa that occur in areas of the NGL with many dreissenids.

10. $N$ and $P$ tolerant (SGL). These taxa are broadly tolerant to higher nutrients in the SGL, including the known eutrophication indicator Cyclostephanos invisitatus (Mortensen, 2013; Reavie et al., 2014a).

\section{Discussion}

Using spatial relationships between phytoplankton assemblage composition and environmental variables, this study demonstrates assemblage shifts in phytoplankton communities along major stressor gradients and identifies species which are most responsive on large scales. Many nutrient-tolerant algal species abruptly and concurrently increased in abundance, while oligotrophic species declined, near the change-points in nutrient gradients and Dreissena abundance; however, in some cases, evidence of community thresholds was not very strong, and responses to water nutrient concentrations could not be estimated from large-scale nutrient loading data. Similar change-points in community composition have been previously observed in several groups of aquatic organisms in response to urbanisation in the surrounding catchments and eutrophication (Baker \& King, 2010; Hilderbrand et al., 2010; King et al., 2011; Smucker, Detenbeck \& Morrison, 2013b; Kovalenko et al., 2014).

The most distinct clustering was associated with NGL (Superior, Huron, Michigan) versus SGL (Erie, Ontario) partition, with many more species responding to stressor gradients in the NGL than in the SGL, likely reflecting the unique characteristics of nutrient dynamics and colimitation in the northern and southern regions (details below). Stronger assemblage responses in spring than in the summer could be due to spring nutrients being a better predictor of algal assemblage dynamics early in the ice-free season. By summer, the uptake of available nutrients by algae minimises this signal by having responses limited to a smaller subset of taxa that are tolerant of nutrient limitation (e.g. cyanophytes in Lake Erie). In addition, summer phytoplankton assemblages may be more affected by zooplankton grazing. Dreissena are also known to elicit the greatest responses in spring phytoplankton (Fahnenstiel et al., 2010; Rowe et al., 2015).

\section{Nitrogen loading, nitrate concentrations and Dreissena abundance}

Water nitrate concentrations were negatively correlated with $\mathrm{N}$ loading in the more oligotrophic northern ecoregion. This may not be surprising because nitrate loading in NGL has increased over the past century (Han \& Allan, 2012) and this is on the scale of water retention time in these lakes (100+ years in Superior). Indeed, our ancillary analysis shows that the relationship between nitrate loading from the atmosphere and nitrate concentrations in the water are dependent on water retention time. In addition, very low phosphorus availability and lower primary production in NGL (Evans, Fahnenstiel \& Scavia, 2011), particularly in Lake Superior, could result in lower nitrate assimilation and reduction, resulting in higher in situ nitrate concentrations despite the lower loading rates, although this was not tested directly in this study. This highlights the potential for significant accumulation of nitrates in ultra-oligotrophic systems with long water residence times even under conditions of low atmospheric inputs. The complex relationship between $\mathrm{N}$ loading and pelagic $\mathrm{N}$ dynamics underscores previously discussed difficulty in predicting nitrogen budgets for large lakes due to uneven historic trends in the major input compartments (Han \& Allan, 2012). The NGL are experiencing increasing nitrate concentrations, particularly prominent in Lake Superior with 

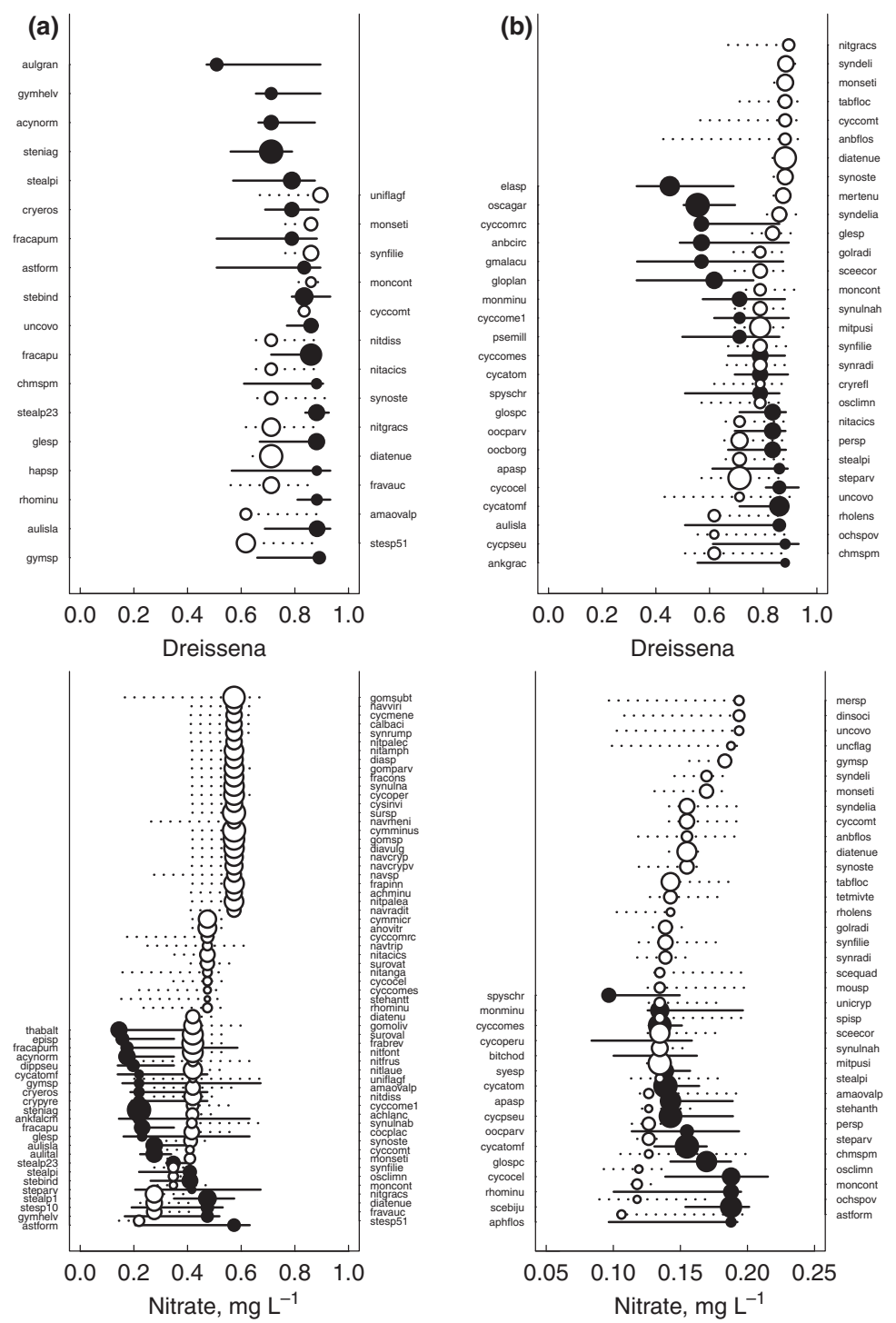

Fig. 6 Phytoplankton community thresholds in SGL (Erie, Ontario) in response to Dreissena, water nitrate and TP in (a) spring and (b) summer. Change-points (0.05- 0.95 bootstrap quantile intervals) are shown for significant sensitive (filled, left side) and tolerant (open) taxa.
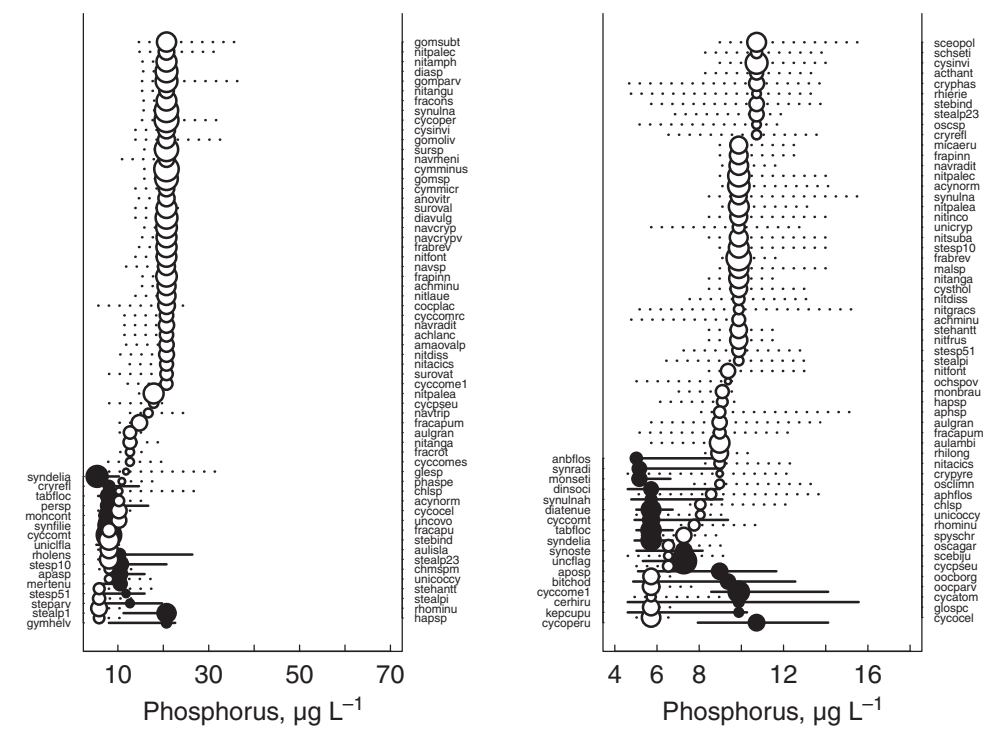


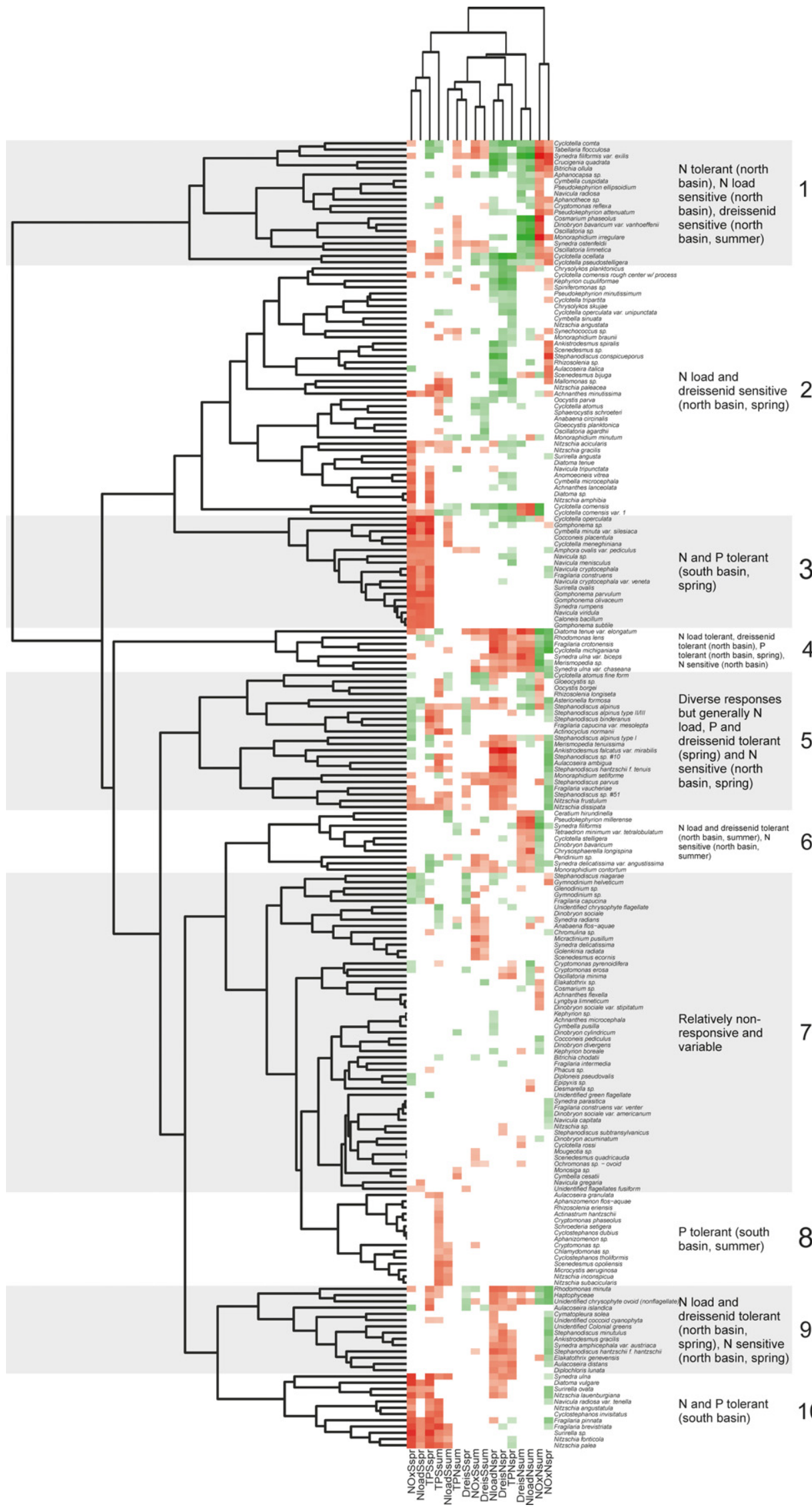

Fig. 7 Heatmap of species response to stressors, including TP, nitrate, $\mathrm{N}$ loading and Dreissena, by NGL and SGL. Colour values reflect relative change in abundance (standardised indicator val-

6 ues, or $z$-scores) for each species and stressor, ranging from strongly responding sensitive or declining (green) to tolerant (red) species. Species overlaps across stressors are shown using cluster analysis, which highlights groups of species with similar responses. For example, the right-most four columns of cluster 4 are

7 a group of species declining in response to nitrate and increasing in response to Dreissena (cluster numbers match those referred to in the text). Each column is a result of a separate TITAN analysis. Note that standardisation is within-test (within-column), so comparison of slight variations in colour intensity (i.e.

8 strength of and specificity of response) is meaningful within each column but less so across columns. See Figs 5 and 6 for change-point locations for individual

9 taxa. Horizontal axes stressor abbreviations are a combination of stressor $\left(\mathrm{NO}_{x}\right.$ - water nitrate concentrations, Nload - N 10 loading, TP - in situ total phosphorus, Dreis - Dreissena densities), season (spr - spring, sum - summer) and region (N - NGL, S - SGL). Zoomable version is available as Figure S2. 
documented fivefold increases in the past century, due to nitrate loading as well as in situ nitrification (Sterner et al., 2007) and a long residence time (Small, Sterner \& Finlay, 2014); therefore, it is critical to understand phytoplankton responses along the nitrogen gradient in the context of other nutrient limitations.

Our results demonstrate that distinct phytoplankton assemblages are associated with low and high ends of the nitrogen gradient. The negative relationship between in situ nitrate and Dreissena densities in the north could indicate that the $\mathrm{N}$ cycle is affected by invasive filterfeeding mussels. These invasive mussels are significant players in nitrogen remineralisation as well as sequestration and biodeposition (Mellina, Rasmussen \& Mills, 1995; Bruesewitz, Tank \& Bernot, 2008; Ozersky, Evans \& Ginn, 2015), yet the balance among those processes is likely dependent on mussel densities, growth rates and lake morphometry. High dreissenid densities in areas with greater $\mathrm{N}$ loadings could result in higher $\mathrm{N}$ sequestration and lower availability of dissolved inorganic nitrogen, but our study was not designed to investigate this connection in more detail. Dreissena also has direct effects on phytoplankton communities, particularly noticeable in reduction of spring phytoplankton blooms (Rowe et al., 2015) and shifting assemblage composition. Changes in assemblage composition occur due to direct filtering of algae from the water column and mussel preferences for certain types of algae (e.g. Cyclotella), whereas others are rejected as pseudofeces (e.g. Microcystis, Lavrentyev et al., 1995; Makarewicz, Lewis \& Bertram, 1999). Algal sinking rates could also be important (Bramburger \& Reavie, 2016). Previous studies demonstrated spring decline in diatom taxa likely as a result of reduced pelagic nutrients and selective consumption (Reavie et al., 2014b). As dreissenid densities (and filtering rates) increase above a certain threshold, pelagic phytoplankton could be shifting to more buoyant and/ or more tolerant of lower pelagic nutrients (e.g. Chrysolykos planktonicus). Overall, different phytoplankton community responses to water nitrate concentrations indicate potential system-specific differences in $\mathrm{N}$ cycling, nutrient co-limitation and effects of dreissenids, and it would be important to disentangle independent effects of Dreissena and nitrates in future studies.

\section{Phosphorus}

Observed community responses to TP concentrations are interesting because they provide insight into potential change-points at the lower end of the phosphorus gradient. Nonlinear algal responses to phosphorus have been previously observed in systems with higher nutrient concentrations such as small lakes (e.g. Scheffer et al., 1997; Giblin et al., 2014; Smith, 2014; Wang et al., 2014) and streams (Smucker et al., 2013b). However, many of the traditional alternative stable states studies did not closely examine species shifts within the phytoplankton assemblage, and considering individual species changepoints may be helpful for anticipating community-wide shifts. It is interesting that our community changepoints, although not very prominent, particularly for sensitive species, were below the proposed target values based on the GL Water Quality Agreement: $8 \mu \mathrm{g} \mathrm{L}^{-1} \mathrm{TP}$ for spring phytoplankton in SGL versus $10 \mu \mathrm{g} \mathrm{L}^{-1}$ proposed as the target for Ontario and Eastern and Central Erie (DePinto et al., 2006). We also note that the dominant community change-points along the phosphorus gradient vary between spring and summer, which is not surprising given the substantial differences between the seasons in terms of assemblage composition and water condition. While mechanisms for these seasonal differences in change-points are probably quite complex, this finding emphasises that one must account for temporal variation when characterising assemblage responses based on synoptic data.

Phosphorus is a well-known driver of phytoplankton abundance and composition in the Great Lakes (e.g. Makarewicz, 1993; Shaw Chraibi et al., 2014). Our results indicate that the abundance of several taxa is clearly correlated with variables other than (or in addition to) phosphorus (e.g. Cyclotella ocellata is tolerant of high $\mathrm{P}$, but is apparently sensitive to higher dreissenid abundance). Future developments may use such information to refine indicator models by accounting for or eliminating species with no apparent response along the gradient of interest (e.g. Racca et al., 2003) or better yet, considering the context of multiple stressors that simultaneously determine patterns in the observed phytoplankton assemblages.

\section{Indicator species}

Despite the lake-specificity of water quality and GLEAM stressors, some general species responses were observed across large areas of the basin. In NGL, lake-specific differences in assemblages were not the primary driving force behind assemblage shifts along the stressor gradients, as indicated by a low proportion of lake-specific indicators. This comparison is more complicated in the SGL because the number of stations in the more nutrient-limited Lake Ontario was smaller than in Lake Erie, the latter also being known for its unique species 
composition (among the GLs) and community dynamics, such as dense spring diatom blooms (central basin) and summer cyanobacterial blooms (western basin) (Reavie et al., 2014b). In addition, Lake Erie experienced complex dynamics of zebra and quagga mussel populations over the past few years (Karatayev et al., 2015b).

We identified clusters of species that could be related to particular stressors, and there is potential to use this information to better understand driving factors behind recent shifts in phytoplankton assemblages. Consider the recent rise in the relative abundance of the centric diatoms Cyclotella sensu lato in the Great Lakes (Shaw Chraibi et al., 2014) and other stratifying northern lakes worldwide (Rühland, Paterson \& Smol, 2008). This phenomenon has been repeatedly associated with recent atmospheric and water warming, but additional and often related factors such as atmospheric nutrient deposition, water clarity and water column stability also need to be considered (Saros et al., 2013). As noted in nearby lakes (e.g. Siskiwit Lake on Isle Royale, Lake Superior; Saros et al., 2012), the role of $\mathrm{N}$ in determining Cyclotella abundance in the Great Lakes is complex. The simple correlation between warming and Cyclotella has been recognised, but given concurrent increases in $\mathrm{N}$ loading in many regions (Holtgrieve et al., 2011), teasing apart driving stressors is difficult. From our data, it is clear that lumping all Cyclotella as preferring higher $\mathrm{N}$ would be erroneous as some taxa are tolerant of higher concentrations (e.g. Cyclotella ocellata) while others are sensitive (e.g. Cyclotella comensis).

\section{Conclusions}

We show that pelagic Great Lakes phytoplankton communities exhibit change-point responses to in situ nutrient concentrations and abundance of invasive mussels across large geographic areas as taxa adapted to low-nutrient conditions are replaced, along the nutrient gradient, by species with higher nutrient optima. The relationship between water nitrate concentrations and nutrient loading was dependent on ecoregion, season and lake water retention time, indicating limited ability to forecast smallscale nutrient dynamics. Potential management applications of this approach and the present findings include development of biologically relevant nutrient criteria and more complete understanding of assemblage responses in a multi-stressor environment. This approach can be adapted for future impacts of stressors such as nutrient loads, invasive species and anthropogenic climate change, as well as more precise characterisation of assemblage responses during state shifts.

\section{Acknowledgments}

We thank the Fred A. and Barbara M. Erb Family Foundation and the University of Michigan Water Center for the generous support of the project 'A comprehensive stressor-response model to inform ecosystem restorations across the Great Lakes basin'. We acknowledge the Great Lakes Environmental Assessment and Mapping Project, and its many data contributors. This research was also supported by a grant to E. Reavie from the U.S. Environmental Protection Agency under Cooperative Agreement GL-00E23101-2. This document has not been subjected to the EPA's required peer and policy review, and therefore, does not necessarily reflect the view of the Agency, and no official endorsement should be inferred. We express gratitude to two anonymous reviewers and Associate Editor, Dr. Alan Steinman for their insightful comments. This is contribution number 615 from the Natural Resources Research Institute, University of Minnesota Duluth.

\section{References}

Allan J.D., McIntyre P.B., Smith S.D.P., Halpern B.S., Boyer G.L., Buchsbaum A. et al. (2013) Joint analysis of stressors and ecosystem services to enhance restoration effectiveness. Proceedings of the National Academy of Sciences of the United States of America, 110, 372-377.

Baker M.E. \& King R.S. (2010) A new method for detecting and interpreting biodiversity and ecological community thresholds. Methods in Ecology and Evolution, 1, 2537.

Barbiero R.P., Rockwell D.C., Warren G.J. \& Tuchman M.L. (2006) Changes in spring phytoplankton communities and nutrient dynamics in the eastern basin of Lake Erie since the invasion of Dreissena spp. Canadian Journal of Fisheries and Aquatic Science, 63, 1549-1563.

Bouwman L., Goldewijk K.K., Van der Hoek K.W., Beusen A.H.W., Van Vuuren D.P., Willems J. et al. (2013) Exploring global changes in nitrogen and phosphorus cycles in agriculture induced by livestock production over the 1900-2050 period. Proceedings of the National Academy of Sciences of the United States of America, 110, 20882-20887.

Bramburger A.J. \& Reavie E.D. (2016) A comparison of phytoplankton communities of the deep chlorophyll layers and epilimnia of the Laurentian Great Lakes. Journal of Great Lakes Research, doi:10.1016/j.jglr.2016.07.004

Bruesewitz D.A., Tank J.L. \& Bernot M.J. (2008) Delineating the effects of zebra mussels (Dreissena polymorpha) on $\mathrm{N}$ transformation rates using laboratory mesocosms. Journal of the North American Benthological Society, 27, 236-251.

(C) 2016 John Wiley \& Sons Ltd, Freshwater Biology, 62, 366-381 
Bunnell D.B., Barbiero R.P., Ludsin S.A., Madenjian C.P., Warren G.J., Dolan D.M. et al. (2014) Changing ecosystem dynamics in the Laurentian Great Lakes: bottom-up and top-down regulation. BioScience, 64, 26-39.

Canfield D.E., Glazer A.N. \& Falkowski P.G. (2010) The evolution and future of Earth's nitrogen cycle. Science, 330, 192-196.

Conley D.J., Paerl H.W., Howarth R.W., Boesch D.F., Seitzinger S.P., Havens K.E. et al. (2009) Controlling eutrophication: nitrogen and phosphorus. Science, 323, 1014-1015.

Cooper M.J., Costello G.M., Francoeur S.N. \& Lamberti G.A. (2016) Nitrogen limitation of algal biofilms in coastal wetlands of Lakes Michigan and Huron. Freshwater Science, 35, 25-40.

Daily J.P., Hitt N.P., Smith D.R. \& Snyder C.D. (2012) Experimental and environmental factors affect spurious detection of ecological thresholds. Ecology, 93, 17-23.

Danz N.P., Niemi G.J., Regal R.R., Hollenhorst T., Johnson L.B., Hanowski J.M. et al. (2007) Integrated gradients of anthropogenic stress in the U.S. Great Lakes basin. Environmental Management, 39, 631-647.

DePinto J.V., Lam D., Auer M., Burns N., Chapra S., Charlton M. et al. (2006). Examination of the Status of the Goals of Annex 3 of the Great Lakes Water Quality Agreement. Technical Report http:/ /www.epa.ohio.gov/portals/35/lakeerie/ptaskforce/Annex\%203\%20Technical\%20Sub-group \%20report-final\%20_120706_.pdf.

Dermott R. \& Geminiuc M. (2003) Changes in the benthic fauna of Lake Ontario 1990-1995, with local trends after 1981. In: State of Lake Ontario (SOLO)-Past, Present, and Future (Ed. M. Munawar), pp. 323-345. Ecovision World Monograph Series. Backhuys Publishers, Leiden.

Dufrêne M. \& Legendre P. (1997) Species assemblages and indicator species: the need for a flexible asymmetrical approach. Ecological Monographs, 67, 345-366.

Elser J.J., Peace A.L., Kyle M., Wojewodzic M., McCrackin M.L., Andersen T. et al. (2010) Atmospheric nitrogen deposition is associated with elevated phosphorus limitation of lake zooplankton. Ecology Letters, 13, 1256-1261.

Evans M.A., Fahnenstiel G. \& Scavia D. (2011) Incidental oligotrophication of North American Great Lakes. Environmental Science and Technology, 45, 3297-3303.

Fahnenstiel G.L., Pothoven S.A., Nalepa T.F., Vanderploeg H.A., Klarer D.M. \& Scavia D. (2010) Recent changes in primary production and phytoplankton in the offshore region of southeastern Lake Michigan. Journal of Great Lakes Research, 36, 20-29.

Falkowski P.G., Fenchel T. \& Delong E.F. (2008) The microbial engines that drive Earth's biogeochemical cycles. Science, 320, 1034-1039.

Gallardo B., Clavero M., Sánchez M.I. \& Vilà M. (2016) Global ecological impacts of invasive species in aquatic ecosystems. Global Change Biology, 22, 151-163.

Galloway J.N., Townsend A.R., Erisman J.W., Bekunda M., Cai Z., Freney J.R. et al. (2008) Transformation of the nitrogen cycle: recent trends, questions, and potential solutions. Science, 320, 889-892.

Gaujoux R. \& Seoighe C. (2010) A flexible R package for nonnegative matrix factorization. BMC Bioinformatics, 11, 367.

Giblin S.M., Houser J.N., Sullivan J.F., Langrehr H.A., Rogala J.T. \& Campbell B.D. (2014) Thresholds in the response of free-floating plant abundance to variation in hydraulic connectivity, nutrients, and macrophyte abundance in a large floodplain river. Wetlands, 34, 413-425.

GLNPO (Great Lakes National Program Office) (2010) Quality Assurance Project Plan for the Great Lakes Water Quality Surveys. U.S. EPA, Chicago.

Han H. \& Allan J.D. (2012) Uneven rise in N inputs to the Lake Michigan Basin over the 20th century corresponds to agricultural and societal transitions. Biogeochemistry, 109, 175-187.

Hecky R.E., Smith R.E.H., Barton D.R., Guildford S.J., Taylor W.D., Charlton M.N. et al. (2004) The nearshore phosphorus shunt: a consequence of ecosystem engineering by dreissenids in the Laurentian Great Lakes. Canadian Journal of Fisheries and Aquatic Sciences, 61, 1285-1293.

Helsel D.R. \& Hirsch R.M. (2002) Statistical Methods in Water Resources Techniques of Water Resources Investigations, Book 4, chapter A3. 522 pp. U.S. Geological Survey. http:// water.usgs.gov/pubs/twri/twri4a3/.

Higgins S.N. \& Vander Zanden M.J. (2010) What a difference a species makes: a meta-analysis of dreissenid mussel impacts on freshwater ecosystems. Ecological Monographs, 80, 179-196.

Hilderbrand R.H., Utz R.M., Stranko S.A. \& Raesly R.L. (2010) Applying thresholds to forecast potential biodiversity loss from human development. Journal of the North American Benthological Society, 29, 1009-1016.

Holtgrieve G.W., Schindler D.E., Hobbs W.O., Leavitt P.R., Ward E.J., Bunting L. et al. (2011) A coherent signature of anthropogenic nitrogen deposition to remote watersheds of the northern hemisphere. Science, 334, 1545-1548.

Karatayev A.Y., Burlakova L.E. \& Padilla D.K. (2015a) Zebra versus quagga mussels: a review of their spread, population dynamics, and ecosystem impacts. Hydrobiologia, 746, 97-112.

Karatayev A.Y., Burlakova L.E., Pennuto C., Ciborowski J., Karatayev V.A., Juette P. et al. (2015b) Twenty five years of changes in Dreissena spp. populations in Lake Erie. Journal of Great Lakes Research, 40, 550-559.

Kelly M.G. \& Whitton B.A. (1995) The trophic diatom index: a new index for monitoring eutrophication in rivers. Journal of Applied Phycology, 7, 433-444.

Kerfoot W.C., Yousef F., Green S.A., Budd J.W., Schwab D.J. \& Vanderploeg H.A. (2010) Approaching storm: disappearing winter bloom in Lake Michigan. Journal of Great Lakes Research, 36, 30-41. 
King R.S. \& Baker M.E. (2010) Considerations for analyzing ecological community thresholds in response to anthropogenic environmental gradients. Journal of the North American Benthological Society, 29, 998-1008.

King R.S., Baker M.E., Kazyak P.F. \& Weller D.E. (2011) How novel is too novel? Stream community thresholds at exceptionally low levels of catchment urbanization. Ecological Applications, 21, 1659-1678.

Kovalenko K.E., Brady V.J., Brown T.N., Ciborowski J., Danz N.P., Gathman J.P. et al. (2014) Congruence of community thresholds in response to anthropogenic stressors in Great Lakes coastal wetlands. Freshwater Science, 33, 958-971.

Kwandrans J., Eloranta P., Kawecka B. \& Wojtan K. (1998) Use of benthic diatom communities to evaluate water quality in rivers of southern Poland. Journal of Applied Phycology, 10, 193-201.

Lavrentyev P.J., Gardner W.S., Cavaletto J.F. \& Beaver J.R. (1995) Effects of the zebra mussel on protozoa and phytoplankton from Saginaw Bay, Lake Huron. Journal of Great Lakes Research, 21, 545-557.

Lozano S.J., Scharold J.V. \& Nalepa T.F. (2001) Recent declines in benthic macroinvertebrate densities in Lake Ontario. Canadian Journal of Fisheries and Aquatic Sciences, 58, 518-529.

Makarewicz J.C. (1993) Phytoplankton biomass and species composition in Lake Erie, 1970 to 1987. Journal of Great Lakes Research, 19, 258-274.

Makarewicz J.C., Lewis T.W. \& Bertram P. (1999) Phytoplankton composition and biomass in the offshore waters of Lake Erie: pre- and post-Dreissena introduction (19831993). Journal of Great Lakes Research, 25, 135-148.

McCann K.S. \& Rooney N. (2009) The more food webs change, the more they stay the same. Philosophical Transactions of the Royal Society of London. Series B, Biological Sciences, 364, 1789-1801.

McCormick P.V. \& Cairns J. (1994) Algae as indicators of environmental change. Journal of Applied Phycology, 6, 509526.

Mellina E., Rasmussen J.B. \& Mills E.L. (1995) Impact of zebra mussel (Dreissena polymorpha) on phosphorus cycling and chlorophyll in lakes. Canadian Journal of Fisheries and Aquatic Sciences, 52, 2553-2573.

Mortensen E. (2013) A diatom-phosphorus transfer function for shallow, eutrophic ponds in southeast England. Nutrient Dynamics and Biological Structure in Shallow Freshwater and Brackish Lakes, 94, 391-410.

Nalepa T.F., Fanslow D.L., Lang G.A., Mabrey K. \& Rowe M. (2014) Lake-Wide Benthic Surveys in Lake Michigan in 1994-95, 2000, 2005, and 2010: Abundances of the Amphipod Diporeia spp. and Abundances and Biomass of the Mussels Dreissena polymorpha and Dreissena rostriformis bugensis. NOAA Technical Memorandum GLERL-164. 21 pp. NOAA, Great Lakes Environmental Research Laboratory, Ann Arbor. http://www.glerl.noaa.gov/ftp/publications/tech_reports/glerl-164/tm-164.pdf.
Nalepa T.F., Fanslow D.L., Pothoven S.A., Foley A.J. III, Lang G.A., Mozley S.C. et al. (2007) Abundance and Distribution of Benthic Macroinvertebrate Populations in Lake Huron in 1972 and 2000-2003. NOAA Technical Memorandum GLERL-140, 33 pp. NOAA, Great Lakes Environmental Research Laboratory, Ann Arbor. http:// www.glerl.noaa.gov/ftp/publications / tech_reports/glerl140/tm-140.pdf.

Ozersky T., Evans D.O. \& Ginn B.K. (2015) Invasive mussels modify the cycling, storage and distribution of nutrients and carbon in a large lake. Freshwater Biology, 60, 827-843.

Racca J.M., Wild M., Birks H.J.B. \& Prairie Y.T. (2003) Separating wheat from chaff: Diatom taxon selection using an artificial neural network pruning algorithm. Journal of Paleolimnology, 29, 123-133.

Reavie E.D., Barbiero R.P., Allinger L.E. \& Warren G.J. (2014b) Phytoplankton trends in the Great Lakes, 20012011. Journal of Great Lakes Research, 40, 618-639.

Reavie E.D., Heathcote A.J. \& Shaw Chraibi V.L. (2014a) Laurentian Great Lakes phytoplankton and their water quality characteristics, including a diatom-based model for paleoreconstruction of phosphorus. PLOS ONE, 9, e104705.

Reavie E.R. \& Barbiero R.P. (2013) Recent changes in abundance and cell size of pelagic diatoms in the North American Great Lakes. Phytotaxa, 127, 150-162.

Rowe M.D., Obenour D.R., Nalepa T.F., Vanderploeg H.A., Yousef F. \& Kerfoot W.C. (2015) Mapping the spatial distribution of the biomass and filter-feeding effect of invasive dreissenid mussels on the winter-spring phytoplankton bloom in Lake Michigan. Freshwater Biology, 60, 2270-2285.

Rühland K., Paterson A.M. \& Smol J.P. (2008) Hemisphericscale patterns of climate-related shifts in planktonic diatoms from North American and European lakes. Global Change Biology, 14, 2740-2754.

Saros J.E., Stone J.R., Pederson G.T., Slemmons K.E., Spanbauer T., Schliep A. et al. (2012) Climate-induced changes in lake ecosystem structure inferred from coupled neoand paleoecological approaches. Ecology, 93, 2155-2164.

Saros J.E., Strock K.E., Mccue J., Hogan E. \& Anderson N.J. (2013) Response of Cyclotella species to nutrients and incubation depth in Arctic lakes. Journal of Plankton Research, 36, 450-460.

Scheffer M. \& Jeppesen E. (1998) Alternative stable states. In: The Structuring Role of Submerged Macrophytes in Lakes (Ed. Jeppesen, E., Sondergaard, M., Sondergaard, M. and Christofferson, K.), pp. 397-406. Volume 131 of the series Ecological Studies, Springer, New York.

Shaw Chraibi V.L., Kireta A.R., Reavie E.D., Brown T.N. \& Cai M. (2014) A paleolimnological assessment of human impacts on Lake Superior. Journal of Great Lakes Research, 40, 886-897.

Scheffer M., Rinaldi S., Gragnani A., Mur L.R. \& van Nes E.H. (1997) On the dominance of filamentous cyanobacteria in shallow, turbid lakes. Ecology, 78, 272-282. 
Small G.E., Sterner R.W. \& Finlay J.C. (2014) An ecological network analysis of nitrogen cycling in the Laurentian Great Lakes. Ecological Modelling, 293, 150-160.

Smith S.D.P. (2014) The roles of nitrogen and phosphorus in regulating the dominance of floating and submerged aquatic plants in a field mesocosm experiment. Aquatic Botany, 119, 1-9.

Smith S.D.P., McIntyre P.B., Halpern B.S., Cooke R.M., Marino A.L., Boyer G.L. et al. (2015) Rating impacts in a multi-stressor world: a quantitative assessment of 50 stressors affecting the Great Lakes. Ecological Applications, 25, 717728.

Smucker N.J., Becker M., Detenbeck N.E. \& Morrison A.C. (2013a) Using algal metrics and biomass to evaluate multiple ways of defining concentration-based nutrient criteria in streams and their ecological relevance. Ecological Indicators, 32, 51-61.

Smucker N.J., Detenbeck N.E. \& Morrison A.C. (2013b) Diatom responses to watershed development and potential moderating effects of near-stream forest and wetland cover. Freshwater Science, 32, 230-249.

Sterner R.W., Anagnostou E., Brovold S., Bullerjahn G.S., Finlay J.C., Kumar S. et al. (2007) Increasing stoichiometric imbalance in North America's largest lake: nitrification in Lake Superior. Geophysical Research Letters, 34, L10406.

Stoermer E.F. (1978) Phytoplankton assemblages as indicators of water quality in the Laurentian Great Lakes. Transactions of the American Microscopical Society, 97, 2-16.

Tilman D. (1982) Resource Competition and Community Structure. Princeton University Press, Princeton.

US Environmental Protection Agency (EPA) (2010) Sampling and Analytical Procedures for GLNPO'S Open Lake Water Quality Survey of the Great Lakes. http://www.epa.gov/ glnpo/monitoring/sop/index.html.
Utermöhl H. (1958) Zur vervollkommnung der quantitativen phytoplankton methodik. Mitteilungen Internationale Vereinigung für Theoretische und Angewandte Limnologie, 9, 1-38.

Wang H.-J., Wang H.-J., Liang X.-M. \& Wu S.-K. (2014) Total phosphorus thresholds for regime shifts are nearly equal in subtropical and temperate shallow lakes with moderate depths and areas. Freshwater Biology, 59, 1659-1671.

Watkins J.M., Dermott R., Lozano S.J., Mills E.L., Rudstam L.G. \& Scharold J.V. (2007) Evidence for remote effects of dreissenid mussels on the amphipod Diporeia: analysis of Lake Ontario benthic surveys, 1972-2003. Journal of Great Lakes Research, 33, 642-657.

Wetzel R.G. (2001) Limnology: Lake and River Ecosystems, 3rd edn. Academic Press, San Diego.

\section{Supporting Information}

Additional Supporting Information may be found in the online version of this article:

Figure S1. Plot of community-level sums of taxon-specific change-points along nitrate, TP and Dreissena gradients.

Figure S2. Zoomable heatmap of species responses to stressors.

Table S1. Details of ANCOVA model.

Table S2. Summary of statistical comparisons for TP and species richness.

Table S3. List of lake-specific species.

Table S4. Summary of phytoplankton change-point locations with respect to all stressors.

Table S5. Species codes, Latin names and reference sources.

(Manuscript accepted 12 October 2016) 